\title{
Economic Analysis of Hybrid Solar Dryer for Ginger Drying
}

\author{
Ramesh Harajibhai Chaudhari, Alok Gora*, V.M. Modi and Hitesh Chaudhari
}
College of Renewable Energy and Environmental Engineering, Sardakrushinagar Dantiwada Agricultural University, Sardarkrushinagar-385506 (Gujarat), India

*Corresponding author

\section{A B S T R A C T}

\begin{tabular}{|l|}
\hline K e y w o r d s \\
$\begin{array}{l}\text { Solar energy, Drying, } \\
\text { Hybrid, Economical } \\
\text { analysis }\end{array}$ \\
\hline Article Info \\
\hline $\begin{array}{l}\text { Accepted: } \\
22 \text { October } 2018 \\
\text { Available Online: } \\
\text { 10 November } 2018\end{array}$ \\
\hline
\end{tabular}

\section{Introduction}

Ginger is one of the most important spice and cash crop of the world. It is being cultivated in India for both as fresh vegetable and as a dried spice. It also has many medicinal properties and sometimes it is used as medicine. Gingerol, an oleoresin in ginger accounts for the aromatic and pungent characteristics, which makes it indispensible in the preparation of food, beverages and medicine (Sundari et al., 2013). It is cultivated in India, China, Japan, Nigeria and Indonesia. India is the largest producer and consumer of ginger contributing about $32.75 \%$ (305900 tons) of total world's ginger production (Aggarwal, 2012). The consumption trend show that $50 \%$ is utilised as green ginger, $30 \%$ is converted into dry ginger and only $20 \%$ used as seed materials. Major market is capture by dried ginger and exported due to its medical properties, which is used in the treatment of stomach ache, nausea, indigestion, asthma etc. (Sundari et al., 2013).

The commercially important spice has to require effective drying so as to attain a very low moisture content to minimize the wastage due to microbial and fungal attacks. Drying has always been of great importance for conserving agricultural products and for extending the food shelf life (Doymaz, 2007). There are different techniques available to dry different food products. The traditional open sun drying method has plenty of disadvantages. The product directly come in contact with dust, insects, rodents, and other animals which seriously degrade the food 
quality and ultimately results in a negative trade potential and economical worth. Varieties of mechanical and electrical energy based dryers are available for preventing the deterioration of products and to reduce the drying time. These conventional dryers and drying techniques are not economical due to high energy cost (Gurlek, 2009).

However, various energy based drying techniques such as heat pump drying, forced convective drying, microwave drying, fluidized bed drying, freeze drying, and many more are available and widely practiced. Diminishing reserves of fossil fuels and increased cost have made drying as an energetically expensive and unaffordable technique for farmers.

In this research paper, a developed hybrid solar dryer system can run by solar energy or electrical energy. An electric energy in hybrid can be used in morning and in evening time for accelerate the drying speed in cloudy condition or low intensity of solar radiation. A number of experimental and theoretical studies have been reported on hybrid drying technology. The focus of the present study is to study the economical feasibility analysis of developed hybrid dryer for drying of ginger.

\section{Materials and Methods}

\section{Experimental setup}

The developed hybrid dryer consist of drying chamber, heating element for supplying extra heat, naturally air flowing went, temperature controller for achieving at desired level and reflector for reflecting the radiation (Fig. 1). The electrical heating system was fitted to the bottom of existing system for accelerate to drying rate in morning and evening time or in cloudy weather. Developed dryer working automatically on solar drying mode or on hybrid mode depends on inside temperature.

\section{Experimental procedure}

Two methods of drying were used here, namely (i) open sun drying by spreading the samples on a cloth and (ii) controlled drying by using the developed hybrid solar dryer. Fresh gingers procured from the local market (Udaipur, Rajasthan, India) and sliced uniformly were used for the experiments. Moisture content of the samples was found by the use of digital moisture analyser (Sartorious M35). A $10 \mathrm{~g}$ of fresh and good quality ginger slices sample prepared for determine the initial moisture content, and kept that inside to digital moisture analyzer for 10 minutes and temperature maintained at $130^{\circ} \mathrm{C}$. Samples of the product were weighed using an electronic balance (D-Sonic Digital scale: $\pm 0.1 \mathrm{~g}$ accuracy). These samples were again weighed and their moisture content was determined on the wet basis method. During experiment drying time, drying temperature, solar intensity, losses of moisture content and ambient temperature were measured. Digital temperature controller (THITHA TDC-96) was used to control the electric heating supply when inside temperature reach on required level during drying.

\section{Drying analysis of ginger}

Moisture content (wet basis) of ginger was determined by following given equation (Ferreira et al., 2007).

$\mathrm{MC}=\frac{\frac{\mathrm{w}_{1}-\mathrm{w}_{2}}{\mathrm{w}_{1}}}{\mathrm{w}_{1}} \times 100(1)$

Where,

$\mathrm{W}_{1}$ is the weight of sample before drying, $(\mathrm{g})$

$\mathrm{W}_{2}$ is the weight of dried sample, $(\mathrm{g})$

Moisture ratio (MR) of ginger was determined by following given equation (Castillo et al., 2018). 
$\mathrm{MR}=\frac{\frac{M-M_{B}}{M_{\mathrm{i}}-M_{B}}}{(2)}$

Where,

$\mathrm{M}$ is the moisture content,

$\mathrm{M}_{\mathrm{e}}$ is the equilibrium moisture

$\mathrm{M}_{\mathrm{i}}$ is the initial moisture content (WB).

Drying efficiency of hybrid solar dryer $(\eta d)$ was determined by following equation (Singh and Verma, 2015).

$\eta_{\mathrm{d}}=\frac{\mathrm{M}_{\mathrm{W}} \times \lambda_{\mathrm{W}}}{\left(\mathrm{A}_{\mathrm{c}} \times \mathrm{I}_{\mathrm{g}} \times \mathrm{t}\right)+\mathrm{Q}_{\mathrm{h}}} \times 100$

Where,

$\eta_{\mathrm{d}}$ is drying efficiency,

$\mathrm{Q}_{\mathrm{h}}$ is heat produced by electric heater $(\mathrm{kW})$,

$\mathrm{M}_{\mathrm{w}}$ is mass of water $(\mathrm{kg})$,

$\lambda_{w}$ is latent heat of vaporization of water $(\mathrm{kJ} / \mathrm{kg})$,

$\mathrm{I}_{\mathrm{S}}$ is solar irradiance $\left(\mathrm{w} / \mathrm{m}^{2}\right)$,

$\mathrm{A}_{\mathrm{c}}$ is total collector area $\left(\mathrm{m}^{2}\right)$ and

$t$ is time required for drying.

\section{Economic analysis}

The economic viability of any system is calculated through economic analysis of the system. For the success and commercialization of any new technology, it is essential to know whether the technology is economically viable or not.

Different economic indicators were used for economic analysis of hybrid solar drying system under this study. The following parameters were considered to carry out cost economics of drying system.

Total capital cost $\left(\mathrm{C}_{0}\right)$ of designed system (Sajith and Muraleedharan, 2014)

The sum of all costs and benefits in a time period is analyzed.
$\mathrm{C}_{0}=$ Cost of materials used for fabrication of system + Labour cost (4)

Net present worth (NPW) of drying system was calculated by following equation (Sajith and Muraleedharan, 2014).

$N P W=\left(\frac{n p-C_{0} a}{d}\right)\left[\frac{(1+d)^{t}-1}{(1+d)^{t}}\right]$

Benefit- Cost ratio of developed drying system was determined by given equation (Sajith and Muraleedharan, 2014).

Benefit cost ratio = total benefit received peryear

capital cost of developed system (6)

The payback period (PP) of developed system was expressed by following equation (Sajith and Muraleedharan, 2014).

$\mathbf{P P}=\frac{\mathbf{C}_{0}}{\left(\mathrm{np}-\alpha \mathbf{C}_{0}\right)}(7)$

Where,

$\mathrm{C}_{0}$ is capital cost of the developed dryer in (₹),

$\mathrm{t}$ is life span of dryer (year), $\mathrm{P}$ is daily benefits received from dryer (₹),

$\mathrm{n}$ is number of days of operation per year (day),

$\alpha$ is repair and maintenance cost (₹),

$\mathrm{d}$ is discount rate $(\%)$.

\section{Results and Discussion}

\section{Drying process}

Drying process was handled for sliced ginger with hybrid solar drying and open sun drying in February month of 2016 at College Of Technology and Engineering, MPUAT Udaipur. 
Figure 2 shows the variance of drying parameters during hybrid solar drying and open sun drying of sliced ginger. The drying of ginger slices were started in morning 9:00 to gain final result on 18:00, during drying time moisture removed by hybrid drying was $79.31 \%$ (wb) initial moisture content to $6.73 \%$ (wb) final moisture content and by open sun drying was $79.31 \%$ (wb) initial moisture content to $66.38 \%$ (wb) final moisture content only. The moisture content was calculated using Equation 1. As per previous study, found good result of developed hybrid dryer than Bhanu and Satyanarayana (2014).

Figure 3 shows the power consumption during hybrid drying time in morning and evening time which was 0.71 watt. In morning and evening time solar irradiance was looking down so electric heater was automatically started and maintain around selected range of $55^{\circ} \mathrm{C}$ for proper drying.

The working process and results of current study are support the previous study, they developed hybrid solar-electrical dryer and performance of dryer was tested for drying of banana slices (Ferreira et al., 2007).
The hybrid solar drying efficiency was found $19.71 \%$. The hybrid solar drying efficiency was calculated using Equation 3. As per previous study, Eke and B.A. was found the greater drying efficiency than developed hybrid solar dryer (Eke, 2013).

The moisture ratio was calculated using Equation 3. During the initial period in hybrid solar dryer, moisture removal rate is high showed in Figure 4. This is due to the fact that the energy required to evaporate the surface moisture is low. After the removal of the surface moisture, drying rate decreases as the energy requirement is more. Relative humidity found low inside the dryer but higher in outside so the drying rate found very slow in sun drying method.

\section{Economic analysis of developed system}

Economic analysis of the developed dryer, the related parameters are taken based on the economic situation in India as shown in Table.1. Cost benefit analysis was done using annualized cost method for ginger drying.

Table.1 The following assumptions were made for the economic assessment

\begin{tabular}{|l|l|l|l|}
\hline S.N. & Assumptions & Values & Unit \\
\hline 1. & Discount rate, $(\mathrm{d})$ & $10 \%$ & $₹$ \\
\hline 2. & Repair and maintenance $(\alpha)$ cost of the capital cost & $5 \%$ & $₹$ \\
\hline 3. & Number of days of operation per year, $(\mathrm{n})$ & 300 & Days \\
\hline 4. & Life span, $(\mathrm{t})$ & 10 & Years \\
\hline 5. & Capital cost of the developed dryer, $\left(\mathrm{C}_{0}\right)$ & 8000 & $₹$ \\
\hline 6. & Electricity cost per kwh & 6 & ₹ \\
\hline
\end{tabular}

Table.2 Economic indicator for hybrid solar drying system for ginger drying

\begin{tabular}{|c|l|l|}
\hline S.N. & Economic indicator & Value \\
\hline 1. & Net Present Worth & ₹ 207000 \\
\hline 2. & Benefit-Cost ratio & 2.3 \\
\hline 3. & Payback period & 6.0 months \\
\hline
\end{tabular}


Fig.1 Diagram of developed hybrid solar dryer with components

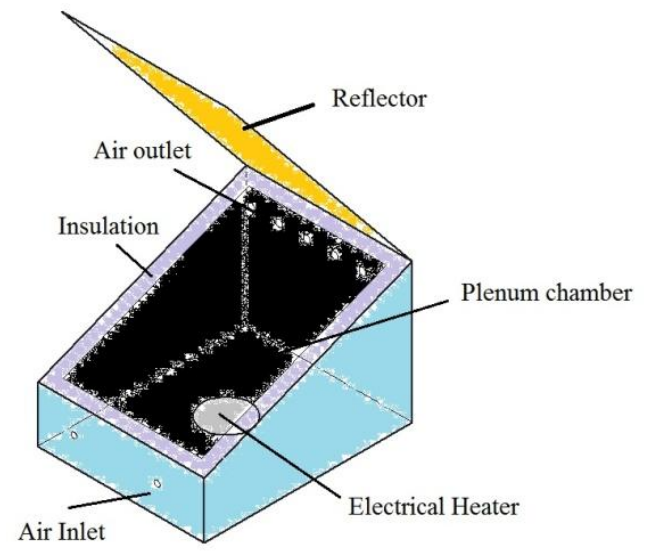

Fig.2 Variations in Ambient and drying Temperature, solar irradiance, and moisture content during open sun drying and hybrid drying

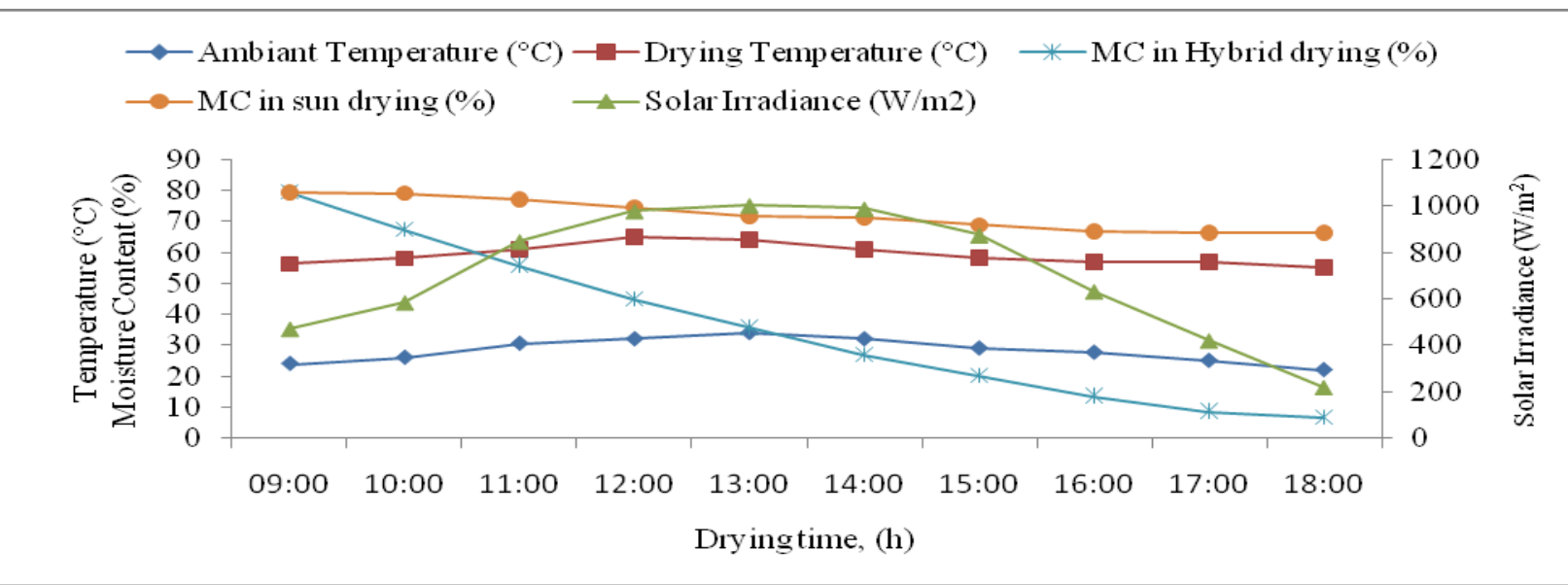

Fig.3 Variations of power consumption and solar irradiance with drying time

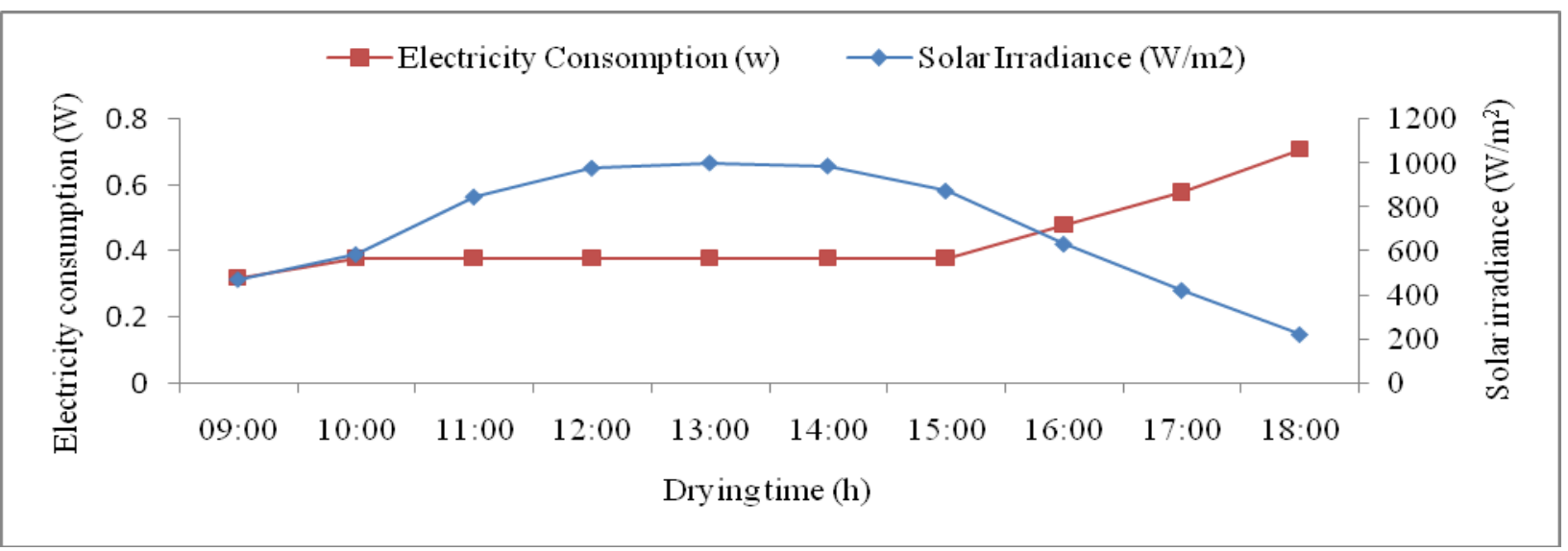


Fig.4 Variations in moisture ratio of both drying method with drying time

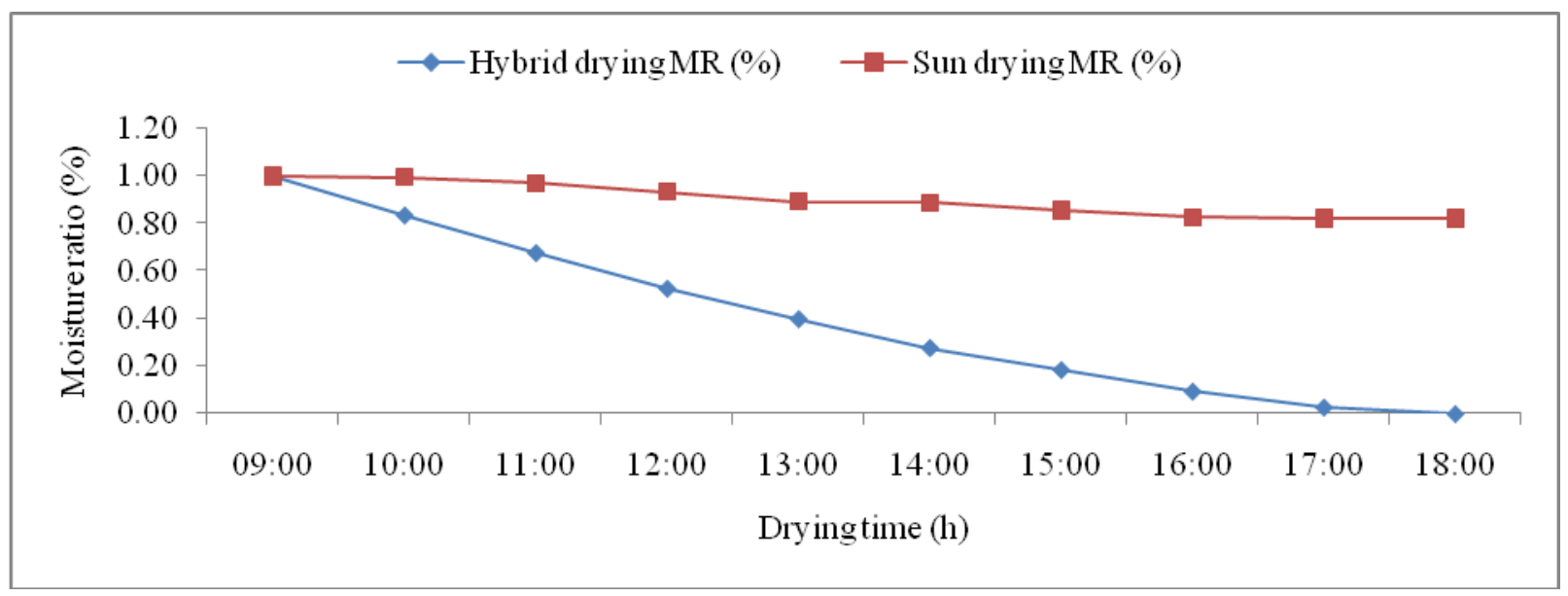

Hybrid solar dryer took 9 hours for drying of $3 \mathrm{~kg}$ ginger. On an average 6 hours are available for drying in a clear sunny day. The 300 days was taken for a year as clear sunny days.

The capital cost of designed system was calculated using Equation 4. The calculated value of capital cost of the hybrid solar dryer is Rs.9000. The annual repair and maintenance cost of the hybrid solar dryer is taken as $5 \%$ of the annual capital cost.

The cost of drying of $3 \mathrm{~kg}$ ginger using the hybrid solar dryer was calculated as Rs.51 per day. The cost of raw ginger in season is taken ₹ 15 per $\mathrm{kg}$. The electricity consumption for drying of $3 \mathrm{~kg}$ ginger is one unit. The market value of dried ginger is ₹ 120 and daily benefit received from drying is ₹ 69. The net present worth of designed drying system for ginger drying is ₹ 20,700 per year. The net present worth of designed drying system was calculated using the Equation 5.

The benefit cost ratio of designed hybrid solar dryer was found to be 2.3. The benefit to cost ratio was calculated using the Equation 6.

The payback period of designed hybrid solar dryer system was 0.50 years $(6.0$ months $)$ only, which is viable and feasible as well. The payback period was calculated using the Equation 7. Payback period is small compared to the life of the hybrid solar drying system. So the hybrid solar drying systems are economical. The results of cost-economic analysis of developed system are shown in Table.2.

An effective hybrid solar dryer for drying of ginger has been developed and tested. The experiments were done for the controlled and open sun drying of the ginger slices samples. The use of hybrid solar dryer considerably reduced the drying time. Thermal performance and drying characteristics was carried out for ginger drying. Economic analysis was carried out to find the net benefit, benefit to cost ratio and payback period. Payback period is small compared to the life of the solar drying system. This clearly establishes the economic viability of the hybrid solar drying systems.

\section{References}

Aggarwal R K (2012) Indirect Solar Drier for drying of Hill products. Asian Journal of Agriculture Rural Development. 2(2): 201-205 
Bhanu P T, and Satyanarayana G (2014) Performance analysis of solar drying system for guntur chili. International Journal of Latest Trends in Engineering and Technology. 4, 871-883.

Castillo Téllez, Erick Cesar López-Vidaña, Isaac Pilatowsky and Anabel L.O (2018) Solar drying of Stevia (Rebaudiana bertoni) leaves using direct and indirect Technologies. Solar Energy 159. 898-907.

Doymaz I (2007) Air-drying characteristics of tomatoes. Journal of Food Engineering. 78 (4): 1291-1297.

Eke B A (2013) Development of small scale direct mode natural convection solar dryer for tomato, okra and carrot. International Journal of Engineering and Technology. 3.

Ferreira A G, Charbel A L, Pires R L, Silva J G, and Maia C B (2007) Experimental analysis of a hybrid dryer. Engenharia Termica (Thermal Engineering). 6, 0307.
Gurlek G, Ozbalta N, and Gung A (2009) Solar tunnel drying characteristics and mathematical modelling of tomato. Journal of Thermal Science and Technology. 29 (1):15-23.

Sajith K G and Muraleedharan C (2014) Economic Analysis of a Hybrid Photovoltaic/Thermal Solar Dryer for Drying Amla. International Journal of Engineering Research \& Technology (IJERT). 3(8): 907-910.

Singh, J., and Verma, P. (2015) Fabrication of hybrid solar dryer. International Journal of Scientific and Research Publications. 5, 2250-3153.

Sundari Umyal A R, Neelamgam P, and Subramanian CV (2013), Study and Analysis of Drying Characteristics of Ginger using Solar Drier with Evacuated Tube Collectors, Research Journal of Pharmaceutical, Biological and Chemical Sciences, 4(3): 12581267.

\section{How to cite this article:}

Ramesh Harajibhai Chaudhari, Alok Gora, V.M. Modi and Hitesh Chaudhari. 2018. Economic Analysis of Hybrid Solar Dryer for Ginger Drying. Int.J.Curr.Microbiol.App.Sci. 7(11): 27252731. doi: https://doi.org/10.20546/ijcmas.2018.711.312 